\title{
The Estonian Turg and the California Certified Farmers' Market
}

\author{
Robert Sommer $\square \quad$ Maaris Raudsepp
}

\section{A 1989 comparison showed the Estonian farmers' market to be su- perior to that country's state-run food stores in quantity and quality of food service, but that farmers' market items were higher in price. Based on surveys, the authors compare the roles played by farm- ers' markets in the economies of Estonia and California.}

Under Mikhail Gorbachev's perestroika (restructuring), Soviet agriculture is moving in the direction of a marketeconomy. However, even during the Stalin years, small market economies existed in the agricultural sector. One interesting example is the farmers' market. As a microcosm of a market economy within a centralized system, the farmers' market may provide clues about what can be expected as Soviet agriculture is restructured.

A farmer producing for sale at a farmers' market has to deal with less bureaucratic control over what crops to plant, how to grow them, and conditions of sale, and can probably expect a higher return than when producing for the state marketing system. On the other hand, the grower has no guaranteed purchase agreement and price, has less access to supplies and services from the state sector, and must expend the time and effort required for direct marketing.

The senior author spent August through December 1989 as a Fulbright scholar in Tallinn, Estonia. This provided an opportunity to extend earlier research on California's Certified Farmers' Markets (CFMs) to the Estonian farmers' market, or turg. We can learn about our own farmers' markets by comparing them with similar institutions in other nations. Knowledge of the Soviet agricultural system and the way it is changing should also be of interest to California agriculturalists interested in export markets.

Estonia is not a typical Soviet republic in that it, along with the other Baltic states of Latvia and Lithuania, was annexed to the USSR under duress. Like 14 of the 15 Soviet republics, it has recently asserted its political independence from Moscow. The government has issued, but not enforced, a declaration of independence. The Estonian economy did not come to follow the Soviet model until 1947. The collectivization of Estonian agriculture that took place at that time wiped out practically all of the 140,000 private farms.

The major agricultural economy became centered around the large collective and state farms, which in 1986 controlled $95.6 \%$ of the total land sown. There is some indication that average yields of major crops declined in the collectivized economy. Production of cereal grains and vegetables on all farms between 1951 and 1955 was only $68.8 \%$ of 1935 to 1939 levels. The situation improved somewhat in the 1960 s relative to pre-War levels, but not to the same degree as in neighboring Finland or in other western nations.

Throughout the period of collectivized agriculture, there remained a small nonstate farm sector composed of leaseholders, weekend farmers, and collective farm employees working on their own time. During visits to collective farms we saw many garden plots and small greenhouses farmed by state employees on their own time. The high productivity of these non-state producers is recognized in current programs to provide land for private farmers.

The Estonian turg has been a major outlet for the private producers. It also has deep historical roots in Estonian society, particularly in the capital city of Tallinn, which has served as a crossroads of traditional trade routes since ancient times. We have identified at least five major marketplaces in Tallinn: Old Market, Big Market, New Market, Russian Market, and Central Market.

Old Market (Vana turg) has been a trade center since pagan times. During the middle ages, only local tradespeople were allowed to buy and sell; regulations prohibited retail sale to foreigners and hawkers. In the nineteenth century, these regulations were relaxed, and hawkers began to operatein rural areas, sparing peasants the long shopping trip into town.

Big Market (Suurturg) was located on the town hall square, the center of town life. The most important civic buildings were located. on the marketplace. The various names for the market reflect occupying forces in Estonia: 1313 — "The Forum"; 1795 — "German Market"; 1809 — "Swedish Market."

The Russian Market (Vene turg) was operated during the eighteenth and nineteenth centuries by Russians who owned and farmed nearby fields. In 1909, the area became a hay market.

The New Market (Uus turg) was created. in 1896 as an overflow of the Big Market, which had become too crowded. Rows of kiosks and counters with sheds wereerected, and in 1900 a building for meat sellers was built. The market buildings were destroyed during 1944 bombings of the city.

The Central Market (Kesk turg), still operating as a farmers' market, has occupied its present site since 1948. Earlier, it was the site of a residential neighborhood destroyed during the 1944 bombing. The general layout of the Central Market is about eight rows of stalls with and withoutsheds and a number of kiosks. A new permanent market building is under construction.

During his stay in Estonia, the senior author shopped regularly at the Central Market and at a suburban market (Nomme turg). These visits were partly out of necessity (daily foraging for food) and partly out of professional interest. The Estonian turg, with its rows of stalls staffed by individual vendors, its festive atmosphere, and its high level of interaction between customer and seller, was a familiar institution. Sellers and customers alike could be transplanted to a California Certified Farmers' Market and play their respective roles without missing a cue. Even the language barrier was not significant at the turg, given the face-to-face interaction between farmers and customers. By contrast, shopping at the state stores with theirlonglines, poorly-stocked shelves, and uninterested employees - required considerable adjustment.

Besides comparing the shopping conditions in Estonian farmers' markets and state food stores, this article makes a similar comparison between California Certified Farmers' Markets and chain supermarkets, the dominant food retailing outlets for California consumers. It seemed more valid for us to look at each farmers' market in the context of the dominantalternative available to local consumers than to directly compare the two types of farmers' market. Our comparisons reveal information aboutSoviet agriculture and also about the different roles farmers' markets play in the two nations.

We got our information on Estonian markets from historical records and from price comparisons and consumer interviews. 
Shoppers at the Central Market (Kesk turg) in Tallinn, Estonia (right), and at the Davis Farmers' Market in Davis, California (below right), can buy a variety of produce direct from local growers.

The information on California CFMs was collected as part of a decade-long research project involving studies of consumer attitudes, prices, food quality, social atmosphere, and effects upon downtown business.

\section{Method}

Researchers visited farmers' markets in three of Estonia's four largest cities. Because of travel restrictions on American scholars in the USSR, we could perform systematic studies only at the Tallinn Central Market and a nearby suburban market.

Price comparisons. During three successive weeks at the Central Market and one week at the suburban market, we recorded the retail prices of fruits and vegetables. Only items sold by weight were used in the comparison, so we did not record prices for produce sold by the bunch, the piece, or the unweighed bag. Also excluded were prepared foods whose quality and ingredients we could not judge. Wherever possible, we got prices from three to five vendors, but if only a single vendor offered the item, we used that vendor's price. Each day, we compared those prices with the prices for the same items at three to five grocery outlets in Tallinn, including the largest supermarket, the major producestore, and several small fruit and vegetable stores.

Tworesearchers toured the entire market tabulating posted prices. If fewer than three prices were posted for a given item, the researchers asked other vendors for prices on a second tour. Customers and vendors normally do not bargain at Estonian turgs (the situation is different in other parts of the USSR), and we observed very little bargaining. Thisimplies that the posted or stated price was the actual selling price. On the second tour of the market, one researcher would ask the price while the other recorded and helped corroborate the response. When the two researchers disagreed about a given price, those data were omitted from the comparison. A check on the validity of the recorded prices was availablein the Estonian agricultural newspaper (MLMaaleht), which lists weekly prices at the major Estonian turgs. Farmers use this information to decide where to sell their wares in order to get the best price. Prices recorded by the researchers at the Central Market and at the suburban market correlated well with the prices published in ML Maaleht.

Interviews. Seventy interviews of customers at the Tallinn Central Market were completed by students in a class taught by the senior author. Questionnaires had been printed in both Estonian and Russian, and the interview was conducted in whichever
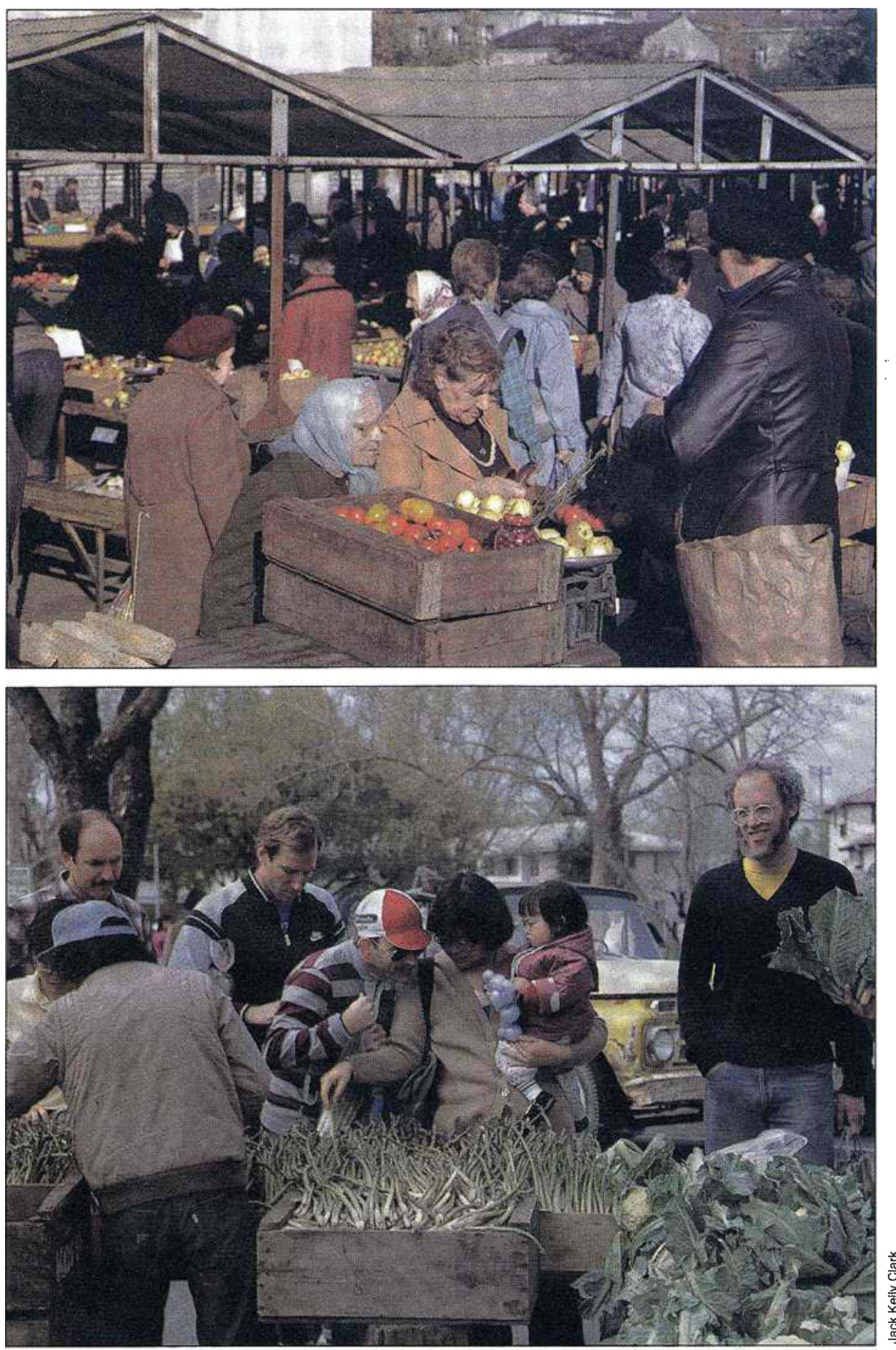

language was appropriate for the customer. The questions were similar to those used in earlier surveys at California's CFMs.

\section{Results}

Prices. In 36 instances, we could make a. direct comparison between prices in the turg and in city stores. Frequent food shortages, particularly in the state stores, kept the number of comparisons lower than it would otherwise have been. Thirty-four of those comparisons showed the average farmers' market price to be higher than the store price, one comparison put the store price higher, and one comparison showed the two prices to be equal. On average, the turg price was $48 \%$ higher than the store price for the same items. The difference was particularly marked for beets, cabbages, and carrots, for which the turg price would be five to ten times higher than the store price.

Ourinterviewsampleincluded 40 women and 30 men (a sex ratio similar to that obtained in customercounts). Eighty-one percent were Estonian, 16\% Russian, and 3\% of other nationalities. Interviewees ranged in age from their teens to their seventies, with an average age of 41 years. A plurality shopped at the turg once a month, and most of these shoppers lived within 1 or $2 \mathrm{~km}$ of the turg. Unlike customers at California CFMs, most of whom reach the market by car, these 
shoppers were almost evenly divided in their mode of transport: $36 \%$ arrived by public transport, $34 \%$ by private car, and $30 \%$ on foot

Respondents wereasked tocompareeight attributes of the turg with those of food stores. Table 1 shows strong consensus (>90\%) on most of the answers. At the turg, consumers perceived a higher quality of food (no one said quality was better at the state stores), better variety, including some specialty items not found elsewhere, shorter lines, more helpful sellers, and a generally more pleasantatmosphere. At the sametime, respondents were virtually unanimous $(97 \%)$ in saying that prices at the turg were higher.

Each of the Estonian turgs had a permanent location. However, in a socialist society, the sites were not "owned" by the markets, they were permanently assigned. Among California CFMs, only the Alemany Market in San Francisco owns its site; all other CFMs rely on the multiple use of other spaces. Having permanent sites, the Estonian markets include a mix of buildings and enclosed stalls. Except for the Alemany Market in San Francisco, weather protection for most California CFMs is minimal, consisting of umbrellas and awnings provided by vendors. The lack of weather protection influences the selling season. All Estonian turgs operate year-round, compared to $59 \%$ of the California CFMs (92 of 156).

The variety of food items available in an Estonian turg is much greater than in the often poorly stocked state-controlled stores. In contrast, California CFMs offer a smaller range of items than commercial supermarkets, which sell out-of-season and non-regional items. The CFM does offer more varieties of seasonal produce, including local varieties that may be absent from commercial wholesale markets. Customers perceive food quality to be higher at farmers' markets than at stores in both Estonia and California. In terms of cosmetic appearance, fruits and vegetables at the turg looked better than what was available in the state stores. One

\begin{tabular}{|c|c|c|c|c|}
\hline \multicolumn{5}{|c|}{$\begin{array}{c}\text { Table 1. Customer ratings }(n=70) \text { of Tallinn } \\
\text { Central Market }\end{array}$} \\
\hline & $\begin{array}{l}\text { Central } \\
\text { market }\end{array}$ & $\begin{array}{l}\text { City } \\
\text { stores }\end{array}$ & Equal & $\begin{array}{l}\text { No } \\
\text { opinion }\end{array}$ \\
\hline \multicolumn{5}{|l|}{ Higher quality } \\
\hline Higher prices & 68 & 1 & 0 & 1 \\
\hline Longer lines & 1 & 62 & 7 & 0 \\
\hline \multicolumn{5}{|l|}{ Greater variety } \\
\hline \multicolumn{5}{|l|}{ Better social } \\
\hline atmosphere & 59 & 5 & 4 & 2 \\
\hline $\begin{array}{l}\text { Sellers more } \\
\text { friendly and } \\
\text { helpful }\end{array}$ & 61 & 0 & 5 & 4 \\
\hline \multicolumn{5}{|l|}{ Specialty items } \\
\hline $\begin{array}{l}\text { elsewhere } \\
\text { ence }\end{array}$ & & 1 & 6 & 2 \\
\hline $\begin{array}{l}\text { More time spent } \\
\text { shopping }\end{array}$ & 8 & 54 & 6 & 1 \\
\hline
\end{tabular}

had the impression that it was up to the customers rather than the management to remove culls in the state stores. The reverse situation is true in California, where the CFM is exempted by statute from many of the size and quality standards required by food marketing orders.

Food prices were perceived as higher at the turg than at the state stores, and lower at the California CFM than at supermarkets in the same city. These perceptions were supported by our systematic price comparisons in both nations.

Lines at the turg were shorter than at state stores. At the stores, customers might waithalf-an-hour even to enter the premises, and face additional delays at counters and checkouts. Long lines are uncommon at California CFMs.

Consumers realistically perceived the turg and the CFM as supporting small farmers. The social atmosphere is a major attraction of both turg and CFM.

All of the Estonian turgs include large flea markets devoted to the sale of clothing and household items. Many of the customers we interviewed had come specifically to buy non-food items, and had purchased. fruits and vegetables on impulse. California CFMs deliberately attempt to avoid a "flea market" appearance.

Consumers rated the sellers at the turg as more friendly to customers than were the sellers at the state stores. The turg vendors were seriously trying to promote their own fruits and vegetables, some to the point of hawking. Workers at the state store, by contrast, were state employees on fixed salaries whose expressed disinterest in customers reflected a lack of incentive for increased sales or friendly service.

The number of organic growers at any single CFM is not large, but they are a distinctive feature of all California CFMs and are appreciated by some customers. There were no indications of organic produce at any of the turgs or state stores visited in Estonia. However, customer interviews revealed some awareness of pesticide issues. A few customers spontaneously mentioned their preference for shopping at the turg, where the fruits and vegetables were grown locally by small farmers, rather than at the state stores, where the produce comes from the large collective farms that use more pesticides.

\section{Discussion}

Within the microcosm of the Estonian turg, our price comparisons and customer interviews support the idea that a market economy can remedy some of the ills of the Soviet food supply system - chronic shortages, limited variety, substandard quality, long lines, and poor service. On the other hand, turgs have shorter hours than state stores, fewer outlets (only two turgs in Tallinn, for example, compared with hun- dreds of retail food stores), and considerably higher prices. In a low-wage society, the 48\%-higher prices at the turg are significant.

Official retail food prices in the USSR are kept artificially low by direct government subsidies. There is little relationship between the true cost of an item and its official price. However, waiting 40 minutes to purchase a kilo of pork that is mostly fat would not be considered a bargain in the West, even at a low price. In order to survive, most Soviet adults work outside the home. This means they have to shop after work, when lines are the longest. Many Soviet women complain that though they work on jobs alongside men, they also have a second job as homemakers, which includes shopping, with its long lines, as well as cooking, housework, and child care. American working women are not unacquainted with a double shift (one at work and the other at home), but the household demands upon Soviet women are more severe in terms of long lines, food shortages, and a lack of time-saving appliances.

Estonian economists told us that the higher food prices at the turg probably reflected production costs more realistically than the subsidized prices in state stores. Since Estonia is moving in the direction of a market economy, the turg may provide guidance to state authorities as they develop realistic market prices. However, the situation is rapidly changing due to the unstable economic and political situation in the USSR and the emergence of a flourishing black market. The findings in this paper are necessarily limited to the 1989 time period during which the research took place.

In 1987, the Baltic states were considered a testing ground for perestroika. With the rising tide of nationalism, reform has slowed in the agricultural sector. The priority list of the Estonian Popular Front places national independence above economic reform, in the belief that the latter is impossible without the former. At present, the turg is a symbol of private farming in a system of collectivized agriculture. If Estonia were to re-establish a western-style economy with democratic institutions, it would include private food stores and chain supermarkets. This would probably diminish the importance of the turg, since small farmers would then be able to sell their produce through commercial channels. However, the inadequacy of the eastern European food distribution system will require some system of local markets to continue for the foreseeable future.

Robert Sommer is Director of the Center for Consumer Research and Professor of Psychology, UC Davis; and Maaris Raudsepp is Research Psychologist at the Tallinn Pedagogic Institute, Tallinn, Estonia. The authors express their appreciation to Ruth Laur and Barbara Sommer for their assistance. 